\title{
The autonomy of the military profession as a condition for civil and democratic control of the military and the fulfillment of the main social role of the military
}

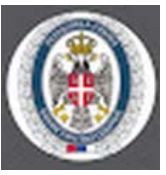

Received: 23/09/2021 Revised: 04/10/2021 Accepted: 08/10/2021 Published: 06/12/2021

Corresponding author: Srđan Starčević

Correspondence email: srdjan.starcevic@vs.rs

DOI: $10.5937 /$ vojdelo2103121S \begin{tabular}{|l|l|l|l|}
\hline c & e & o & n \\
\hline c & e & e & s \\
\hline
\end{tabular}

\author{
Srđan Starčević, Srđan Blagojević \\ Univerzitet odbrane u Beogradu, Vojna akademija
}

\begin{abstract}
:
The interference of the military in politics in a state is indisputably disastrous for its democracy. However, even the "too tight grip" of civil control of the military can be dangerous for a society, if its result is suboptimal or misused military power. The purpose of civil and democratic control of the military is to create a social environment in which the military accepts democratic values and does not pose a threat to the functioning of democracy, while maintaining a high level of professional efficiency and integrity. Therefore, it is necessary to simultaneously find a solution to the civil-military paradox and preserve the professional autonomy of officers from the challenges that come from the sphere of politics. Starting from Huntington's theory of civil-military relations, using a case study and the hypothetico-deductive method, this paper shows that the autonomy of the military profession is one of the conditions for proper functioning of civil and democratic control of the military, and that respecting and strengthening professionalism of officers is a necessary condition for preserving and developing the military capabilities to successfully carry out its missions and tasks. The understanding of civil and democratic control of the military as a process by which a dynamic balance between its participants is achieved is also propagated.
\end{abstract}

Keywords: civil and democratic control of the military; social role of the military; military efficiency; officer profession; obedience

\section{INTRODUCTION}

According to Weber's well-known understanding of the state, the condition for maintaining an order, which this political organization with the character of a public institution guarantees and in which it achieves its purposes, is that its administrative apparatus establishes a monopoly of legitimate physical coercion in its territory [1]. The state body through which the mentioned monopoly is established and maintained is the military. This results in the special importance of the military for the state and the maintenance of order, i.e. the predictability of the validity of laws, and hence the trust in laws, which follows from the belief that they will always be valid, regardless of whether threats to order arise internally (e.g. in the form of armed rebellion) or externally (e.g. in the form of armed aggression) [2]. However, the very fact that the military, as a state body, is at the same time the strongest armed force in the state, raises questions about the possibilities of the state civil administrative apparatus to subordinate the military and control it. The military can become socially independent, and officers can see themselves as a partial social group with their own interests or understand the military as an institution of national importance, whose mission is to achieve the whole of national interests, as opposed to political parties that represent only partial interests (parts of interests). Having in mind, on the one hand, the superior organization of the military and its weapons, and on the other hand its social role, there is no option of physical subordination of the military. As this question is synthesized by Finer, it is not unusual for the military to sometimes "rebel against civil masters, and to never listen to them" [3].

In order to limit military power to the sphere of military affairs, civil control of the military is established. It exists both in democracies and non-democracies, but in these two cases it is based on differ- 
ent values and implemented in various ways, although the essence of that control - establishing harmony between military activities and the ruling value system in the society - is the same [4]. At the same time, since it is important for the state to have optimal armed forces, this control should be such as not to reduce the capability of the military below the level that allows it to successfully respond to its main social role - defending the state from external armed threats. For civil and democratic control of the military, this means that it has to resolve the civil-military paradox. In addition, it has to provide the neutrality of the military, more precisely: its non-participation in the political struggle for power. Therefore, the problem of civil and democratic control of the military is complex and cannot be reduced to the establishment and maintenance of the supremacy of political power that ensures that the military accepts the mechanisms and outcomes of democratic political processes in the state. It has to prevent the transfer of military power into political power, without destroying it or making it suboptimal. Moreover, it has to elevate political power, but in such a way that it does not lead to the instrumentalization of the military in politics or its politicization in narrower sense.

\section{HUNTINGTON'S BALANCE AND SWORD ON POLITICAL STAGE}

Establishing control over the professional bodies of the state apparatus is a challenge, especially when it comes to the military [5]. In the second half of the 2oth century, important theories of civilmilitary relations considered this problem and offered their solutions, and many of them have been implemented in practice [6]. Huntington's theory of civil-military relations is of particular importance, which was first criticized, but soon became influential. In particular, Huntington's "advice to democratizers" was implemented in many countries during the process of transition to democracies, in the late 20th and early 21st century [7].

The more subtle conclusions of Huntington's analyses of civil-military relations, unfortunately, have remained insufficiently understood. First of all, it is necessary to emphasize Huntington's observation about the existence of strong civil control of the ruling party over the military in one-party regimes, as well as the fact that democratic forces after the fall of one-party regimes had less problems to establish civil control over the military than those that inherited military juntas and personal dictatorships. The main challenge for them, in Huntington's opinion, referred to the processes of arranging that the military does not belong to any party and recovery of officers' professionalism, in which the inconvenient legacies of totalitarianism were removed [7].

Considering the influence of various ideologies on civil-military relations, Huntington concluded that conservatism is most compatible with military values. The concept of a balance is close to conservatism because for the preservation of a system it is important that the forces acting in it are in a mutual balance. The idea of a balance was introduced into conservatism by Edmund Burke. Responding to remarks about his own inconsistent attitude on the civil revolutions in the United States and France, Burke said he felt "the need to contribute to those forces that are capable to restore the balance of a rocking ship and is therefore in danger" [8].

In Huntington's theory of civil-military relations, the idea of a balance plays a key role'. Huntington noticed that there are two variants of civil control of the military: subjective and objective [9]. Subjective one seeks to establish control over the military by diminishing military power and/or involving military personnel in politics, but its bad consequence is the creation of suboptimal armed forces, insufficiently capable of responding to their main social role, as well as the politicization of officers that favours loyalty over competence. Noticing this, Huntington advocated the execution of objective control of the military, which would preserve the efficiency of the military. He believed that objective civil control requires a balance between military power and social ideology, and called for the creation of "a conservative environment in the United States" [9]. However, apart from this external balance, which mostly consists of mutual compatibility of military and social values, another, internal balance can be found in Huntington's objective civil control, which ensures the existence of civil control of the military without diminishing military power and disrupting military efficiency. The main idea of objec- 
tive civil control of the military is political sterilization of the military by strengthening officers' professionalism, with the implied autonomy of the military profession that guarantees optimal efficiency of the military ${ }^{2}$. This implies subordinating the military to political leaders elected to adequate positions in the state, so that military intervention in the field of politics does not jeopardize democracy, and also the obligation of political leaders to respect military professionalism and its field of expression, so that incompetent civil intervention in military affairs does not threaten military efficiency in performing its main social role [9]. The military, therefore, is subject to political power, and political power recognizes that there is military activity as an autonomous field dominated by professional military competence (rather than political will). Thus, only what Huntington called military political power is reduced, while political power and military power are in a kind of mutual respect, division of roles and balance.

Although Huntington's theoretical concept of a balance of political and military power, with the maximization of the first and the autonomous field of the second power, seems simple, practice shows that it is a matter of a dynamic balance; and where there is dynamics, there are struggles of opposites. Huntington himself noticed different types of situations in which obedience and professional competence, as two highest virtues of military professionals, can come into a conflict or be challenged by other values. He analyzed these conflicts of values at an ethical level and mostly resolved them in favour of obedience, albeit with a clear attitude that there is a field in which officer competence cannot be replaced - and should not be suppressed-by political will. However, the sacralization of obedience led Huntington even to condemn those German generals who opposed Hitler [9].

The most famous critic of Huntington's objective civil control of the military was Samuel Finer, who pointed out the possibility of a conflict between political power and military professionalism, as well as the danger of a technical understanding of the society by military experts, so he brought the debate back to the beginning, wondering how much autonomy we could allow the military at all. Finer concluded that professionalism is not the solution for civil and democratic control of the military, but the establishment of the supremacy of political power [4].

Indeed, the danger of social independence of the military, its apostasy from the government and rulers and acting as an independent political entity has been pointed out by many philosophers and scientists, and it is an important part of many historical and contemporary political events ${ }^{3}$. The clearest explanation of the essence of the danger that threatens the state from the military came from Maurice Duverger, who claims that the military is, by its nature, always dangerous for the state because the misuse of weapons (armed force) is a part of the abuse of power as such. "Weapons are the ultimate expression of power, the most crucial in short term, and the most irresistible at the moment. The one who holds a sword falls, naturally, into the temptation to throw it on scales. Armed soldiers are a constant danger to the government and unarmed citizens [10]." Duverger believes that this danger can be avoided by developing an officer's sense of obedience to the state, "regardless of its form and who is represented by its managers [10]." However, he does not elaborate on this thesis, which can be explained by the social context in which these reflections arose. Nevertheless, one can still consider the dangers that threaten the society and democratic order if the autonomy of the officer profession, whose value Huntington emphasized so much, is abolished by the demand for obedience.

Such thoughts have two directions. The first refers to cases in which political influence penetrates deep into the sphere of officer competence and whose ultimate result is an inefficient army. In this case, what we have called the internal balance in Huntington's theory of civil-military relations is grossly disturbed. Political will suppresses professional officer competence, crushes its potential resistance and discourages differences of opinion and reasoned criticism of the existing or newly adopted solutions. The ultimate consequence of such a state is defeat in war and loss of freedom. Duverger's theme varies in the other direction: "The one who holds a sword naturally falls into the temptation to throw it on scales [10]". If the military is subordinated to instrumentalization to such an 
extent, isn't that also dangerous for the state, its laws and democracy? For example, the military can be politicized by the so-called daily politics, be used in official campaigns or political power over it can be abused for the purpose of corrupt activities ${ }^{4}$. Ultimately, can a civilian who instrumentalizes the military throw a sword on scales? Political history confirms this [11][13]. What, in terms of values, has served as leverage of abuse is the imposition of obedience to the military as the only important requirement for the military in civil-military relations. A sublime and necessary value, separated from other values that complement and correct it, is often abused. In modern society, this problem is actualized by the crisis of democracy and the rise of populism, phenomena that contemporary authors in social sciences pay due attention ${ }^{5}$. Basically, it is an old problem of power that concentrates on the top and power that has a tendency to expand indefinitely. The concentration of power in the hands of a small number of interest-related people and the overflow of their power beyond the limits of competences and law leads to the degradation of institutions. The result is that dominant power is strengthened, but the society and state mechanisms (institutions) weaken. "Every independent power and control function has disappeared from all these institutions [12]."

\section{AN ESSAY FROM CONTEMPORARY CIVIL-MILITARY RELATIONS}

Huntington published his observations on civil-military relations in the second half of the 2oth century, with a fresh memory of World War II and under the threat of the Cold War and the challenges of the Post-Cold War world. However, some events in the 21st century vehemently prove the importance of the theory of civil-military relations and the complexity of the good functioning of civil and democratic control of the military. Such an event took place in the Republic of Austria in 2011. It is a conflict between the Chief of Defence Staff of the Armed Forces of the Republic of Austria General Edmund Entacher and the Minister in the Austrian government in charge of defence, Norbert Darabos - two members of the Social Democratic Party of Austria - over the reform of the Austrian Armed Forces and the transition from conscription to professional army. This example illustrates very well the possibilities for tensions between political power and officer competence in modern democracies. Namely, at the end of 2010, Minister Darabos announced his plan for the reform of the Austrian Armed Forces, which included the reduction of defence costs through the suspension of military service and the staged transition to professional army. However, General Entacher opposed this attempt, publicly expressing his professional opinion on the issue, in an interview to "Profile" magazine, published on January 22, 2011. He said that the changes that would occur on the basis of such a difficult-to-correct decision are risky and without future [14]. He later expressed doubts that it was possible to reduce the costs of defence by transition to professional army, especially when one has in mind the functions that the military performs in a neutral state such as Austria. Two days later, the Minister recalled the disobedient General from the position of the Chief of Defence Staff and appointed him to a lower position, stating that Entacher had lost his trust [15]. The Austrian public saw this decision as an expression of the Minister's arbitrariness, and Entacher received a written decision on his recall, which he could appeal against, only a few months later. He hired a lawyer, continued his dialogue with the public and defended professional attitudes, pointing out, among other things, that he had been illegally recalled. He got the support of professional officer associations, some civil society organizations, as well as the President of Austria at that time, Heinz Fisher, also a member of the Social Democratic Party of Austria. The Government Appeal Commission declared the Minister's decision to recall General Entacher illegal, in November 2011, and Entacher was brought back to the position of the Chief of Defence Staff, and retired in 2013. Nevertheless, he continued to publicly express his disagreement with Minister Darabos's reform course and the wave of pacifism on the Austrian political scene [17][18][19]. The debate on the suspension of military service received an epilogue in the referendum in 2013, in which the citizens of Austria decided to continue military service [16][20].

The questions about the problems of civil-military relations that can be asked in connection with the described case are numerous. Huntington argues that officers have a triple responsibility to the state because of their representative, advisory and executive function [9]. According to his theory, an officer is obliged to perform the first two mentioned functions, always bearing in mind that there are limitations in that, while the third function is above these two. The real question is what officers 
should do when they are denied the opportunity to perform the first two functions, in accordance with the theory of democratic elitism that refutes the autonomy of the military profession, especially if there is a real danger that executing incompetent decisions will result in suboptimal army [21]? The theory of democratic elitism in this case shows two shortcomings. The first one is in the field of competences and refers to the lack of knowledge of decision-makers regarding military affairs and defence, which can be significantly corrected by public debate and the existence of bureaucratic systems, in Weber's sense of the word. This shortcoming is, however, exacerbated if acted upon arbitrarily, while avoiding the mentioned two corrections. The second shortcoming is the understanding of the functioning of "government of the people": the theory of democratic elitism is based on the understanding that the people elect the political elite, and that it, having been elected, has a legitimate right to make important decisions. It is interesting that this postulate of democratic elitism is based on the understanding that voters are not competent for all kinds of decisions, while the political elite is [22]. In the described case, it was seen that the conflict had an epilogue in the referendum, so it could be concluded that this second shortcoming can be mitigated by the mechanisms of direct democracy, which should be the case when it comes to the most important issues. However, if General Entacher had not opposed the Minister, the decision would have been made without a valid public debate and without checking the will of the people.

Another great question arises at the meeting place of political and military power - in strategy. Huntington also recognized strategy as a field of encounter between politics and military competence, but gave priority to politics [9]. Among Yugoslav authors, Petar Tomac explained with similar arguments that waging war had outgrown military competence and had become the job of statesmen [23]. We can agree with the arguments about the complexity and political height of modern strategy and war, but there is no guarantee that a politician is necessarily more competent than an officer in analyzing, understanding and developing new strategies or generating different decisions and courses of action. In the belief in the competence of politicians, there is something of the old mystifications of the ruler's knowledge of the state reason, which is incomprehensible to his subordinates [24]. Coming to power and exercising power in a mystical way are connected with knowing the state reason. There is no mystique in modern state: professional state bodies (should) represent a bureaucratic and technocratic mechanism by which important political decisions, arising from the expressed will of the people, are operationalized and executed in an appropriate manner and in accordance with valid laws, and also a pool of human resources, which is an important generator of competent ideas, analyses, proposals and solutions. This also refers to the field of defence and military security. However, as Stjepan Domjančić rightly noticed, in the last decades, strategy has left the field of security and defence, and officers seem to have withdrawn from strategy to the field of operations and tactics in which they feel more comfortable [25]. If we understand the essence of strategy in the slogan endsways-means, it can be accepted that politics defines goals, distributes and allocates funds and chooses ways, but in order to have realistic goals and pre-ideologically adequate means and ways, these decisions, at least when it comes to defence issues, have to contain military expertise. After all, do important issues, such as the choice of the type of the army from the mentioned example, belong to military or political sphere? The answer is that it belongs to both. If expertise is to be respected, then the proposals come from military sphere, and their selection is made in political sphere. However, we cannot choose something that has not even been offered for choice.

The third great question is about responsibility: who is responsible for creating suboptimal army (and future war defeat)? The simplest answer is that the state creates, equips and shapes its army, so a statesman has the majority of the burden of responsibility. However, officers, as the most competent persons for military affairs, are also responsible for the suboptimality of the military. It is the obligation of the state to maintain an optimal army, but it has to rely on officer competence [21].

The importance of the military can be derived from its role in meeting social needs for protection and security, as well as from the role of the state in guaranteeing order. That is why it is necessary for the military to function as an efficient state body. The optimal armed forces are characterized by efficiency, and their characteristics as institutions are subject to determination that other state bodies do not 
have. Many features of the military are defined by the nature of the armed struggle, and its members are obliged by oath to perform tasks that involve the risk of death. At the same time, professional members of the armed forces are often people who, choosing the military profession, renounce some rights and freedoms. For example, in the Republic of Serbia, professional military personnel renounces the right to political organization and membership in political parties, as well as passive suffrage, which is the great renunciation of rights for each citizen ${ }^{6}$. This renunciation has its justification that follows the logic of civil and democratic control of the military, and also the professional logic that makes the armed forces an effective superorganism. As a professional body, the military has many features of a bureaucratic institution in Weber's sense, and particularly illustrative examples are education, training and advancement of officers, strategic planning, equipping and orientation of military commanders to accomplish missions and tasks of the armed forces. Like every profession, the military profession has its applied ethics and its standards of competence. Respect for professional military ethics and the achievement of professional competences are a condition for the proper performance of officer duties. At the same time, officer profession is firmly connected with the state power, in both directions: it is connected by command relation with the supreme command authority, which is an element (organ) of political system, but it is also the profession that the state entrusts power over the military organizational units ${ }^{7}$. Officers command units and manage important functions in the defence system, being qualified by professional competence and professional experience.

Officer competence is also the basis from which it is sometimes only possible to obtain decisions by "boiling", as Sartori says. As it has been seen in Entacher's case, sometimes officers will be forced to defend their professional opinion in order to make an adequate decision and, at the same time, avoid the one that puts the military in a situation that it cannot fulfill its social role, and the society in a danger of not being able to meet a social need for security.

\section{CONCLUSION}

The crisis of democracy at the beginning of this century has confirmed what could already be found in Huntington's books: that the "too tight grip" of civil and democratic control of the military could have its bad consequences. Just as military power produces democratically unfavourable results when intervening in politics, the excess of civil power can lead to various abuses that lead, on the one hand, to a decline in the military efficiency in regard to its ability to respond to its social role, and on the other hand, into the instrumentalization of the military dangerous to democracy.

Civil and democratic control of the military implies the harmonization of military activities with dominant social values, but its essence is to create an environment and mechanisms due to which the military respects democracy and remains neutral in the political race for power, without losing any of its features that make it effective in the armed struggle. As Ilija Kajtez summarizes in a sentence: "The society must and should respect the uniqueness and difficulty of the military profession to the same extent as professional soldiers respect the electoral will of citizens" [26].

\section{Acknowledgment}

The paper was written as a part of the research on the scientific project of the MilitaryAcademy of the Defence University „The military in the political system of Serbia”, which isfinanced by the Ministry of Defence of the Republic of Serbia (project number VA-DH/1/19-21).

\section{Endnotes}

'Huntington used the word balance in the title of the final chapter and in the title of a subchapter of his book The Soldier and the State [9].

${ }^{2}$ Autonomy is a word of Greek origin which means the independence or autonomy of certain territories or social groups in making and implementing their own decisions [27]. 
${ }^{3}$ According to research, in the first decade of the 21 st century, as many as $19 \%$ of countries in the world had experience with the military rule [28]. The most famous cases of coups after that occurred in Egypt (2013), Zimbabwe (2017), Sudan (2019), Algeria (2019), Mali (2020), Myanmar (2021) and Guinea (2021).

${ }^{4}$ Although the military has its own mechanisms for suppressing corrupt activities, as a hierarchical organization it has characteristics that make it vulnerable in this regard. Presenting obedience as the highest virtue of military personnel, along with disabling other virtues that complement it, facilitates corruption. Endemic corruption makes it impossible for the military to carry out its missions and tasks effectively, just as it destroys the universal values of justice, the common good and freedom on a wider social level [29][30].

${ }^{5}$ For example, the Serbian Political Science Association organized scientific conferences with variations on this topic [31][32].

${ }^{6}$ Such solutions were adopted in FR Yugoslavia [33] Compare: [34].

${ }^{7}$,An officer is the only official who the State ... has given general authority of its sovereign power because it has placed citizens in his hands, and forced them to fully obey him ..." [35].

\section{REFERENCES}

1. Abenheim Donald, Halladay Carolyn. Achieving neutrality and effectiveness: Austria. In: Bruneau ThomasC, Florina CristianaMatei, editor(s). The Routledge Handbook of Civil-Military Relations. London: Routledge. 2013; p. 296-303. [Google Scholar]

2. Babić Jovan. Ogledi o odbrani. Beograd: Službeni glasnik. 2018. [Google Scholar]

3. Blagojević Veljko. The impact of neutrality on National doctrine development. In: Alliance planning and coalition Warfare: Historical and contemporary approaches. Wien + Beograd: Heeresgeschichtliches Museum + Institut za strategijska istraživanja. 2019; p. 280-300. [Google Scholar]

4. Bonavida Iris. Edmund Entacher: 'Reform lebensbedrohlich'. Die Presse. [Internet]. 2012 [cited 10. september 2021]. Available from: https://www.diepresse.com/733453/edmund-entacher-reform-lebensbedrohlich.

5. Čupić Čedomir. Politika i pohlepa - ogledi o ljudskoj pohlepi, korupciji i borbi protiv korupcije. Beograd: Fakultet političkih nauka Univerziteta u Beogradu + Čigoja štampa. 2016. [Google Scholar]

6. Diverže Moris. Uvod u politiku. Beograd: Savremena administracija. 1966. [Google Scholar]

7. Domjančić Stjepan. Why strategy has come out from security and defence area? In: Marković Dragana, editor(s). Asymmetry and Strategy. Belgrade: Strategic Research Institute + National Defence School + Media Center 'Odbrana'. 2018; p. 531-546. [Google Scholar]

8. Đorđević Biljana, ur. Konstitucionalizam i ustavni dizajn u demokratskoj recesiji. Beograd: Udruženje za političke nauke Srbije + Univerzitet u Beogradu-Fakultet političkih nauka. 2018. [Google Scholar]

9. Escriba-Floch Abel, Böhmelt Tobias, Pilster Ulrich. Authoritarian regimes and civil-military relations: Explaining counterbalancing in autocracies. Conflict Management and Peace Science. 2020;37(5):559-579. [Google Scholar]

10. Finer SamuelE. The man on horseback: The role of the military in politics. New Jersey: Transaction Publishers (US). 2002. [Google Scholar]

11. Fritzl Martin, Prior Thomas. General Entacher, der Held der Beamten. Die Presse. [Internet]. 2011 [cited 10. september 2021]. Available from: https://www.diepresse.com/706967/general-entacher-der-held-derbeamten.

12. Geddes Barbara, Frantz Erica, Wright JosephG. Military Rule. Annu Rev Polit Sci (Palo Alto). (17):147-162. [Crossref] [Google Scholar]

13. Hantington SemjuelP. Treći talas - demokratizacija na kraju dvadesetog veka. Beograd: Stubovi kulture. 2004. [Google Scholar]

14. Hantington SemjuelP. Vojnik i država - teorija i politika civilno-vojnih odnosa. Beograd: Fakultet političkih nauka + Diplomatska akademija. 2004. [Google Scholar]

15. Latić Enis. Rizici korupcije u sektoru odbrane. In: Pravo i izazovi XXI vijeka - korupcija. Brčko: Evropski univerzitet Brčko distrikt. 2014; p. 230-236. [Google Scholar]

16. Mićunović Dragoljub. Demokratija, populizam, entropija. Beograd: Arhipelag. 2018. [Google Scholar]

17. Pavlović Vukašin. Država i društvo. Beograd: Čigoja štampa. 2011. [Google Scholar]

18. Prutsch MarkusJ. Caesarism in the Post-Revolutionary Age: Crisis, Populace and Leadership. London: Bloomsbury Academic. 2020. [Google Scholar] 
19. Purger Alexander. Ex-Generalstabschef Entacher: 'Die Bubis und Bobos wollen das Heer einfach nicht'. Tiroler Tageszeitung. [Internet]. 2020 [cited 10. september 2021]. Available from: https://www.ttcom/artikel/17176262/ex-generalstabschef-entacher-die-bubis-und-boboswollen-das-heer-einfach-nicht

20. Rukavishnikov Vladimir, Pugh Michael. Civil-Military Relation. In: Caforio Giuseppe, editor(s). Handbook of the Sociology of the Military. Cham: Springer. 2018; p. 123-143. [Google Scholar]

21. Sartori Đovani. Demokratija, šta je to?. Podgorica: CID. 2001. [Google Scholar]

22. Stanar Dragan. Demokratija, stručnost i lojalnost - sistem plena ili oligarhija eksperata. Zbornik Matice srpske za društvene nauke. 2019(172):551-561. [Crossref] [Google Scholar]

23. Tomac Petar. Ponovo dileme. In: Radonić Mićo, editor(s). Vojna nauka. Beograd: Vojnoizdavački zavod. 1971; p. 46-52. [Google Scholar]

24. Vujačić Ilija, Vranić Bojan. Urušavanje ili slom demokratije?. Beograd: Udruženje za političke nauke Srbije + Univerzitet u Beogradu-Fakultet političkih nauka. 2016. [Google Scholar]

25. Vračar Milinko, Stanojević Goran. Strateška kultura Srbije i koncept totalne odbrane. Vojno delo. 2019;71(8):294-315. [SCIndeks] [PDF] [Google Scholar]

26. Vujanić Milica, et al. Rečnik srpskog jezika (izmenjeno i popravljeno izdanje). Novi Sad: Matica srpska. 2011. [Google Scholar]

27. Gave Andre. Veština komandovanja. Beograd: VINC. 1993. [Google Scholar]

28. Gostović Dragan. Vojska u političkom sistemu druge Jugoslavije. Nacionalni interes - časopis za nacionalna i državna pitanja. 2021;17(2):41-62. [Google Scholar]

29. Gostović Dragan. Vojska u političkom sistemu SR Jugoslavije. In: Blagojević Srđan, Starčević Srđan, editor(s). Vojska i politički sistem. Beograd: MC 'Odbrana'. 2021. [Google Scholar]

30. Kajtez Ilija. Sociologija. Beograd: Vojna akademija + MC 'Odbrana'. 2019. [Google Scholar]

31. Stanar Dragan. Politička korektnost u vojničkim čizmama - etički izazovi implementacije principa jednakosti ishoda u vojsci. Kultura polisa. 2020(42):401-413. [Google Scholar]

32. Starčević Srđan. Samokontrola kao vid demokratske civilne kontrole vojske. Vojno delo. 2011;63(1):242-255. [SCIndeks][PDF] [Google Scholar]

33. Starčević Srđan, Blagojević Srđan. Uloga služenja vojnog roka u razvoju srpske strateške kulture. Vojno delo. 2020;72(4):85-104. [Crossref] [SClndeks] [PDF] [Google Scholar]

34. Starčević Srđan, Kajtez Ilija. Berkov doprinos proučavanju vojske kao društvene institucije. Teme. 2018;42(3):779-797. [Crossref] [Google Scholar]

35. Starčević Srđan. Revolucija i legitimnost. Beograd: Čigoja štampa. 2020. [Google Scholar] 


\title{
Autonomija vojne profesije kao uslov civilne demokratske kontrole vojske i ostvarivanja osnovne društvene uloge vojske
}

\begin{abstract}
Sažetak:
Mešanje vojske u politiku u jednoj državi nesporno je pogubno za njenu demokratiju. Međutim, i "prečvrst stisak" civilne kontrole vojske može da bude opasan za jedno društvo, ukoliko je njegov rezultat suboptimalna ili zloupotrebljena vojna moć. Smisao civilne demokratske kontrole vojske jeste stvaranje društvenog ambijenta u kojem vojska prihvata demokratske vrednosti i sama ne predstavlja opasnost za funkcionisanje demokratije, zadržavajući visok nivo profesionalne efikasnosti i integriteta. Dakle, neophodno je istovremeno pronaći rešenje za civilno-vojni paradoks i sačuvati profesionalnu autonomiju oficira od izazova koji dolaze iz sfere politike. Polazeći od Hantingtonove teorije civilno-vojnih odnosa, koristeći studiju slučaja i hipotetičko-deduktivnu metodu, u ovom radu se pokazuje da je autonomija vojne profesije jedan od uslova dobrog funkcionisanja civilne demokratske kontrole vojske, kao i da je poštovanje i jačanje profesionalnosti oficira neophodan uslov za očuvanje i razvoj sposobnosti vojske da uspešno izvrši svoje misije i zadatke. Propagira se i shvatanje civilne demokratske kontrole vojske kao procesa kojim se postiže dinamička ravnoteža između njegovih učesnika.
\end{abstract}

Ključne reči: civilna demokratska kontrola vojske; društvena uloga vojske; vojna efikasnost; oficirska profesija; poslušnost 